\title{
Leverage, Beta, Growth Opportunities, Firm Size, dan Earnings Response Coefficient Perusahaan Otomotif dan Komponennya
}

\author{
Lisdawati $^{1}$, JMV. Mulyadi ${ }^{2}$, Hermiyetti ${ }^{3}$ \\ ${ }_{1,2}$ Universitas Pancasila, Jl. Raya Lenteng Agung, Jagakarsa, Jakarta Selatan, 12640 \\ 3 Universitas Bakrie, Jl.H.R Rasuna Said Kav C-22, Kuningan Jakarta
}

I N F O A R T I K E L

JEL Classification:

G14

G30

\section{Keywords:}

earnings response coefficient, leverage,

systematic risk (beta), growth opportunities, firm size.

\section{A $B$ S T R A C T}

This research is purposed to analyze the influence of factors affect earnings response coefficient (ERC), partially and simultaneously, which consist of leverage, systematic risk (beta), growth opportunities, and firm size. The sample in this study are 12 automotive and components listed firms..This research use secondary data which applies multiple linear regression model to analyze and test the influence of independent variables to dependent variable partially (t-test), simultaneously (f-test), and goodness of fit (R-square) on models. The results showed that simultaneously, systematic leverage, systematic risk (beta), growth opportunities, and firm size effect on earnings response coefficients. Partially, Leverage has a negative effect on earnings response coefficient, Beta negatively correlated to earnings response coefficients, Growth opportunities (Market To Book Value ratio) has a significant effect on earnings response coefficients, size companies (FirmSize) has significant effect on earnings response coefficients.

\section{A B S T R A K}

Penelitian ini bertujuan untuk menganalisa faktor-faktor yang mempengaruhi koefisien respon laba (ERC), secara simultan dan parsial, yang terdiri atas leverage, resiko sistematik (beta), Growth opportunities (Market To Book Value rasio), dan ukuran perusahaan (Firm Size). Sampel adalah 12 perusahaan otomotif dan komponennya.Penelitian ini menggunakan data sekunder yang mengaplikasikan model regresi multiple linear untuk menganalisa dan menguji pengaruh variabel independen terhadap variabel dependen secara parsial (t-test), simultan (f-test), dan goodness offit (R-square) pada model penelitian. Hasil penelitian menunjukkan bahwa Leverage, Beta, Growth opportunities (Market To Book Value rasio) dan Size secara bersama-sama (simultan) berpengaruh terhadap variabel terikat (dependent variable) koefisien respon laba. Secara parsial Leverage berpengaruh negatif terhadap koefisien respon laba, secara parsial Beta berkorelasi negatif terhadap koefisien respon laba, secara parsial Growth opportunities (Market To Book Value rasio ) berpengaruh signifikan terhadap koefisien respon laba, secara parsial ukuran perusahaan (FirmSize) berpengaruh signifikan terhadap koefisien respon laba 


\section{Pendahuluan}

Pernyataan standar akuntansi keuangan (PSAK) No.1 menyatakan laba memiliki manfaat untuk menilai kinerja manajemen, membantu mengistimasi kemampuan laba yang representative dalam jangka panjang, memprediksi laba dan menaksir resiko dalam investasi atau kredit (FASB,1985). Salah satu unsur dalam laporan keuangan yang paling banyak diperhatikan dan dinanti-nantikan informasinya adalah laporan laba rugi, suatu laporan yang memberikan informasi mengenai laba (earnings) yang dicapai oleh perusahaan dalam suatu periode.

Laba yang berhasil dicapai oleh suatu perusahaan merupakan salah satu ukuran kinerja dan menjadi pertimbangan oleh para investor atau kreditur dalam pengambilan keputusan investasi atau untuk memberikan tambahan kredit, perusahaan yang melaporkan laba yang tinggi tentu akan menggembirakan para investor yang menanamkan modalnya karena mereka akan mendapatkan deviden atas tiap kepemilikan saham yang dimilikinya. Informasi laba merupakan referensi bagi investor untuk menanamkan investasinya kepada perusahaan tersebut karena earnings, baik positif maupun negatif yang diperoleh dari laporan rugi-laba perusahaan akan mempengaruhi return saham. Besarnya pengaruh ini akan rendah, khususnya untuk earnings yang negatif (rugi). Umumnya dalam mengetahui kualitas laba yang baik dapat diukur dengan menggunakan earnings response coefficient (ERC), yang merupakan bentuk pengukuran kandungan informasi dalam laba. Pengertian koefisien respon laba (earnings response coefficient) adalah didefinisikan sebagai efek setiap dolar unexpected earnings terhadap return saham, dan biasanya diukur dengan slopa koefisien dalam regresi abnormal returns saham dan unexpected earning.

Penelitian yang lebih spesifik meneliti tentang ERC adalah penelitian Mulyani, dkk (2007) tentang faktor-faktor yang mempengaruhi earnings response coefficient pada perusahaan yang terdapat di Bursa Efek Jakarta. Dengan menggunakan beberapa faktor yang selalu dihubungkan dengan ERC pada penelitian sebelumnya, penelitian tersebut berusaha mencari tahu hubungan atau pengaruh antara persistensi laba,struktur modal, beta atau risiko, kesempatan bertumbuh dan ukuran perusahaan dengan earnings response coefficient. Dengan pemikiran diantaranya bahwa semakin permanen perubahan laba dari waktu ke waktu maka semakin tinggi koefisisen laba karena kondisi ini menunjukkan bahwa laba yang diper oleh perusahaan meningkat terus menerus, selain itu kaitannya dengan struktur modal, perusahaan dengan tingkat leverage yang tinggi berarti memiliki utang yang lebih besar dibandingkan modal, dengan demikian apabila terjadi peningkatan laba maka yang diuntungkan adalah debtholders .

Penelitian lainnya mengenai faktorfaktor yang mempengaruhi ERC dilakukan oleh Indra, dkk (2008). Dari empat faktor yang dapat mempengaruhi kualitas laba hanya beta dan market to book value ratio yang memiliki pengaruh signifikan terhadap resiko kualitas laba, sedangkan variabel lainnya, yaitu leverage dan size tidak berpengaruh secara signifikan terhadap kualitas laba, tetapi secara empiris, terdapat pengaruh yang signifikan antara variabel independen levarage, beta, market book value ratio, serta firm size secara bersama-sama terhadap ERC pada perusahaan properti dan real estate yang terdaftar di Bursa Efek Indonesia pada tahun 2004-2008.

Berdasarkan latar belakang di atas maka penulis tertarik untuk menganalisis kembali faktor-faktor yang berhubungan dengan ERC. Pada penelitian terdahulu beberapa variabel yang diuji memberikan hasil berbeda. Dengan asumsi konteks, waktu penelitian dan objek atau sample yang diteliti berbeda maka penelitian dapat menghasilkan kesimpulan yang berbeda pula. Faktor-faktor yang digunakan dalam penelitian ini adalah leverage, risiko sistematik yang diproksikan dalam beta pasar, kesmpatan bertumbuh yang diproksikan dengan market to book value ratio, dan ukuran perusahaan (firm size). 


\section{Telaah Teori dan Pengembangan Hipotesis}

Signaling Theory dalam penelitian ini menjelaskan bahwa manajemen perusahaan sebagai pihak yang memberikan sinyal berupa informasi laba dalam laporan keuangan perusahaan. Teori sinyal menyatakan bahwa perusahaan yang berkualitas baik dengan sengaja akan memberikan sinyal pada pasar dalam bentuk informasi, dengan demikian pasar diharapkan dapat membedakan perusahaan yang berkualitas baik dan buruk. Jika pengumuman laba tersebut sebagai sinyal baik (good news) bagi investor, yaitu kenaikan laba perusahaan, maka reaksi yang ditimbulkan terhadap harga saham adalah kenaikan harga saham, dan demikian pula sebaliknya

Definisi Laporan Keuangan menurut Standar Akuntansi Keuangan (SAK) di konvergensi ke IFRS yang dikeluarkan oleh Ikatan Akuntan Indonesia (IAI), yaitu: "Laporan keuangan bagian dari proses pelaporan keuangan. Laporan keuangan yang lengkap biasanya meliputi: Laporan posisi keuangan, laporan laba rugi konferhensif, laporan perubahan posisi keungan yang disajikan dalam berbagai cara (seperti laporan arus kas atau arus dana), catatan dan laporan lain suatu materi penjelasan yang merupakan bagian integral dari laporan keuangan. Disamping itu termasuk schedule dan informasi tambahan yang berkaitan dengan laporan tersebut, misalnya informasi keungan segmen industri dan geografis serta pengungkapan pengaruh harga". Laporan tahunan (annual report) dan laporan keuangan (financial report) merupakan media utama penyampaian informasi oleh menajemen kepada pihak-pihak diluar perusahaan. Laporan tahunan mengkomunikasikan kondisi keuangan dan informasi lainnya kepada pemegang saham, kreditor dan stakeholder lainnya. Laporan keuangan merupakan sarana yang penting bagi investor untuk mengetahui perkembangan perusahaan secara periodik. Semakin cepat investor menerbitkan laporan keuangan baik yang audited financial statement ataupun yang anaudited financial statment, semakin berguna bagi investor.

Kualitas laba dapat diindikasikan sebagai kemampuan informasi laba memberikan respon kepada pasar. Dengan kata lain, laba yang dilaporkan memiliki kekuatan respon (power of response). Kuatnya reaksi pasar terhadap informasi laba yang tercermin dari tingginya earnings response coefficients (ERC), menunjukkan laba yang dilaporkan berkualitas. Scott (2000), Cho dan Jung (1991) dalam Etty (2008) menyatakan bahwa Earnings Response Coefficient (ERC) mengukur seberapa besar return saham dalam merespon angka laba yang dilaporkan oleh perusahaan yang mengeluarkan sekuritas tersebut. Dengan kata lain earnings response coefficient (ERC) adalah reaksi atas laba yang diumumkan (published) oleh perusahaan. Reaksi ini mencerminkan kualitas dari laba yang dilaporkan perusahaan. Dan tinggi rendahnya earnings response coefficient (ERC) sangat ditentukan kekuatan responsif yang tercermin dari informasi ( good/ bad news) yang terkandung dalam laba. Earnings response coefficient (ERC) merupakan salah satu ukuran atau proksi yang digunakan untuk mengukur kualitas laba (Collins, et al. 1984).

\section{Pengaruh Leverage terhadap Earnings Response Coefficient}

Perusahaan dengan tingkat leverage yang tinggi berarti memiliki utang yang lebih besar dibandingkan modal. Dengan demikian jika terjadi peningkatan laba maka yang diuntungkan adalah debtholders, karena debitor mempunyai keyakinan bahwa perusahaan akan mampu melakukan pembayaran atas hutang. Namun hal ini akan direspon negatif oleh investor karena investor akan beranggapan bahwa perusahan akan lebih menguntungkan kreditur karena lebih mengutamakan pembayaran hutang daripada pembayaran dividen. sehingga semakin baik kondisi laba perusahaan maka semakin negatif respon pemegang saham. Hasil pengujian yang dilakukan oleh Mulyani etal. (2007) menunjukkan bahwa leverage keuangan berpengaruh secara signifikan terhadap earnings response coefficient (ERC). Etty (2008) menyatakan terdapat pegaruh 
negatif antara Leverage terhadap Earnings Response Coeficient (ERC). Hasil penelitiannya sejalan dengan Dhaliwal, et al. (1991) dalam Etty (2008) yang membuktikan bahwa Leverage berpengaruh negatif terhadap koefisien respon laba yaitu Earnings Response Coefficient (ERC).

$\mathbf{H}_{1}$ : Terdapat pengaruh yang negatif antara Leverage, terhadap Earnings response coefficient.

\section{Pengaruh Risiko Sistematik (Beta) terhadap Earnings Response Coefficient}

Investor akan mengurangi tingkat risiko yang diterimanya dengan mempertimbangkan risikospesifiksuatuperusahaandalampengambilan keputusan investasinya. Sensitivitas investor terhadap informasi mengenai perusahaan berisiko kecil akan lebih besar karena perusahaan dengan risiko lebih kecil lebih dipercaya (Palupi, 2006). Penelitian Mulyani et al. (2007) menunjukkan bahwa risiko sistematik berhubungan negatif dengan ERC. Sejalan dengan penelitian yang dilakukan Collins dan Kothari (1989) bahwa risiko (riskness) yang menunjukkan variasi antar perusahaan, dan risk-free interest rate yang menunjukkan variasi antar waktu terbukti secara empiris berpengaruh negatif signifikan dengan earnings response coefficient berbeda dengan penelitian yang dilakuan oleh Palupi (2003) menyatakan terdapat pengaruh yang signifikan antara resiko sistimatik (beta) terhadap Earnings response coefficient.

$\mathbf{H}_{2}$ : Terdapat pengaruh yang positif antara Beta, terhadap Earnings response coefficient.

\section{Pengaruh Kesempatan bertumbuh ()terhadap Earnings Response Coefficient}

Kesempatan bertumbuh Collins dan Kothari (1989) menunjukkan bahwa perusahaan yang memiliki kesempatan bertumbuh yang lebih besar akan memiliki earnings response coefficient tinggi. Kondisi ini menunjukkan bahwa semakin besar kesempatan bertumbuh perusahaan maka semakin tinggi kesempatan perusahaan mendapatkan atau menambah laba yang diperoleh perusahaan pada masa mendatang.

Penelitian yang lain dilakukan Andyani (2007) menyatakan terdapat pengaruh signifikan antara Growth Opportunities (Market to Book value ratio) terhadap Earnings response coefficient secara parsial.

H4 : Kesempatan bertumbuh berpengaruh signifikan terhadap earnings response Coefficient.

\section{Pengaruh Ukuran Perusahaan (Firmn- Size) Terhadap Earnings Response Coefficient}

Ukuran Perusahaan Ukuran perusahaan merupakan proksi dari keinformatifan harga. Perusahaan besar dianggap memiliki informasi yang lebih banyak dibandingkan perusahaan kecil. Konsekuensinya semakin informative harga saham maka semakin kecil pula muatan informasi earnings sekarang. Walaupun demikian Easton dan Zmijewski (1989) menunjukkan bahwa besaran perusahaan bukan variabel penjelas yang signifikan untuk earnings response coefficient .Penelitian lain juga dilakukan. Mulyani, dkk (2007) menyatakan terdapat pengaruh signifikan Firm Size terhadap Earnings response coefficient secara parsial.

H5 : Ukuran perusahaan berpengaruh signifikan terhadap earnings response Coeefficient.

\section{Metode}

Populasi yang digunakan dalam penelitian ini adalah perusahaan go public yang ada di Bursa Efek Indonesia (BEI). Periode penelitian meliputi jangka waktu 5 tahun. Cara pengambilan sampel berdasarkan purposive sampling atau penilaian (judgment)dengan tujuan untuk melihat pengaruh ketiga variabel terhadap industri otomotif dan komponen. Data yang digunakan dalam penelitian ini adalah data sekunder, yaitu laporan keuangan yang diperoleh dari Pusat Referensi Pasar Modal Bursa Efek Indonesia. Laporan keuangan tahunan diterbitkan perusahaan-perusahaan otomotif dan komponen yang terdaftar di BEI, Indonesian Capital Market Directiry (ICMD), JSX Statistics, IDF Quarterly Statistics, IDX Montly Statistics, Fact Book dan Daftar Kurs Efek (DKE).

Pemilihan sampel dalam penelitian ini penulis mengambil 12 perusahaan otomotif dan komponen yang memenuhi kriteria kelengkapan 
Tabel 1. Operasionalisasi Variabel

\begin{tabular}{|c|c|c|}
\hline Variabel & Indikator & Referensi \\
\hline $\begin{array}{l}\text { Earnings } \\
\text { Response } \\
\text { Coefficient } \\
\text { (ERC) } \\
(\mathrm{Y})\end{array}$ & $\begin{array}{l}\text { - Abnormal return sekuitas ke-i pada periode peristiwa } \\
\text { ke } t \\
\text { - Return saham ke- } i \text { pada periode peristiwa ke } t \\
\text { - } \text { Return ekspektasi sekuritas ke- } I \text { pada periode peristiwa } \\
\text { ke } t \quad I A R_{i, t}[t 1-t 2]=\sum A R_{i, t=1} \mid \\
\text { - } \text { Unexpected earnings perusahaan } i \text { pada periode (tahun) } \\
\quad t \\
\text { - Laba akuntansi perusahaan } i \text { pada periode (tahun) } t \\
\text { - Laba akuntansi perusahaan } I \text { pada periode (tahun) } \\
\text { sebelumnya }(t-1) \\
\qquad U E_{i t}=\frac{\left(E_{i t}-E_{i t}-1\right)}{E_{i t}-1}\end{array}$ & $\begin{array}{l}\text { Brown dan } \\
\text { Warner, } 1985 \\
\text { Suaryana (2004) }\end{array}$ \\
\hline Leverage(X1) & $\begin{array}{l}\text { - Total hutang } \\
\text { - Total aseet } \\
\quad L e v_{i t}=\frac{\boldsymbol{U}_{t}}{\mathbb{H}_{t}}\end{array}$ & Dhaliwal (1991) \\
\hline $\begin{array}{l}\text { Risiko sistematik (Beta) } \\
(\mathrm{X} 2)\end{array}$ & $\begin{array}{l}\text { - Return perusahaan } i \text { tahun } t \\
\text { - Beta yang merupakan koefisein yang mengukur } \\
\text { perubahan Ri akibat perubahan } \mathrm{Rm} \\
\text { - Return pasar pada tahun } t \\
\text { Rit }=\alpha \mathrm{i}+\beta \text { it } \mathrm{Rmt}+\text { eit }\end{array}$ & Hartono, 2003 \\
\hline $\begin{array}{l}\text { Growth } \\
\text { Opportunities(Market } \\
\text { to book value ratio) (X3) }\end{array}$ & $\begin{array}{l}\text { - Nilai pasar ekuitas } \\
\text { - Nilai buku ekuitas } \\
\text { Nilai pasar ekuitas } \\
\text { Nilai buku ekuitas }\end{array}$ & Jaswad, 2003 \\
\hline $\begin{array}{l}\text { Ukuran perusahaan } \\
\text { (Firm Size), (X4) }\end{array}$ & - Total aktiva & Collins dan Kothar, 1989 \\
\hline
\end{tabular}

data dari tahun 2008 - 2012, sepenuhnya dilakukan berdasarkan pertimbangan dengan kriteria sebagai berikut :

a) Perusahaan otomotif dan komponen yang terdaftar di BEI

b) Memiliki laporan keuangan tahun 20082012

c) Memiliki data return saham (closing price) hari pertama setelah tanggal penerbitan laporan keuangan.

Pengukuran variabel terangkum pada tabel 1.

Teknik analisis yang digunakan adalah analisis regresi linier berganda, yaitu analisis yang digunakan untuk mencari adanya hubungan antara dua variabel independen atau lebih terhadap satu variabel dependen. Model yang digunakan dalam penelitian ini yaitu:

$$
\begin{aligned}
E R C \text { it }= & \beta 0+\beta 2 L E V \text { it } 1+\beta 3 \text { Betait }+\beta 4 M B \text { it }+ \\
& \beta 5 \text { SIZEit }+\varepsilon i t
\end{aligned}
$$

Keterangan :

$\mathrm{ERC}_{i t}=$ Koefisien respon laba perusahaan $i$ pada perioda $t$

$\mathrm{LEV}_{i t}=$ Struktur modal perusahaan $i$ pada perioda $t$

Betait $=$ Risiko sistematik (beta) perusahaan $i$ pada perioda $t$ 
MBit $=$ Pertumbuhan perusahaan $i$ pada perioda $\underline{t}$

SIZEit $=$ Ukuran perusahaan $i$ pada perioda $t$

Berikut ini adalah cara untuk mendeteksi munculnya gejala penyimpangan dari ketiga asumsi klasik di atas. (1) Multikolinieritas, untuk menguji multikolinieritas dengan melihat nilai VIF $=1 /(1-r 2)$, jika mendekati 1 berarti multikol tidak berbahaya(Gujarati, 1995).(2)Autokorelasi, untuk mendeteksi adanya gejala autokolerasi ini dapat digunakan uji Durbin-watson test.(3) Heterokedastisitas, untuk mendeteksi adanya heterokedastisitas dapat dilakukan dengan cara uji korelasi Rank Sperman.

\section{Hasil Penelitian dan Pembahasan}

Deskripsi statistik memberikan gambaran atau deskripsi tentang data yang ditunjukkan pada nilai rata-ratanya (mean), standar deviasi, varian, maksimum dan maksimum serta skewness (kemencengan distribusi). Berikut akan dijelaskan tentang leverage, beta, growth oportunities dan firm size pada perusahaan otomitif dan komponen yang terdaftar di BEI selama tahun 2008-2012.

Dari Tabel 2 menunjukkan bahwa nilai $\mathrm{n}$ sebanyak data perusahaan yang digunakan dalam penelitian yaitu 60 sampel. Tabel di atas diperoleh gambaran sebagai berikut:

1. rata-rata 0,52 ; dan nilai standar deviasi sebesar 0,19 . Artinya bahwa pertumbuhan aset rata-rata hanya mencapai $52 \%$.

2. Beta (Risiko) memiliki nilai minimum sebesar -1.82 ; nilai maksimum sebesar 1,71 ; nilai rata-rata 0,94 ; dan nilai standar deviasi sebesar 0,42 . Oleh karena itu tingkat risiko sistimatis mencapai rata-rata dibawah 1 , relatif sangat rendah dibandingkan rata-rata tingkat risiko perusahaan di Bursa Efek Indonesia.

3. Growth opportunities memiliki nilai minimum sebesar 0,22 ; nilai maksimum sebesar 9,04; nilai rata-rata 1,71 ; dan nilai standar deviasi sebesar 1,59. Demikian pula tingkat ekspektasi pertumbuhan penjualan ratarata pertahun hanya mencapai $1,17 \%$ pada simpangan baku sebesar $1,59 \%$, juga masih relatif rendah selama periode penelitian, karena pada tahun 2008 sampai 2012 terjadi krisis dunia, sehingga sangat fluktuatif.

4. Firm Size memiliki nilai minimum sebesar 25,65; nilai maksimum sebesar 32,84; nilai rata-rata 28,41; dan nilai standar deviasi sebesar 1,74. Oleh karena itu pertumbuhan aset mencapai rata-rata $28,41 \%$ relatif sangat tinggi dibandingkan rata-rata industri yang mencapai 5 hingga $10 \%$ pertahun.

Dari hasil pengolahan data tersebut diatas, dapat disimpulkan bahwa kondisi per-tumbuhan perusahaan Otomotif dan Komponen selama periode penelitian menunjukkan per-tumbuhan yang relatif rendah dibanding per-tumbuhan ratarata pada perusahaan industri.

Uji asumsi klasik terdiri dari uji normalitas, multikolineritas, heteroskedastisitas dan uji autokorelasi. Uji normalitas dilakukan dengan menggunakan gambar p-plot seperti pada gambar I.

Tabel 2. Hasil Pengujian Statistik Deskriptif

\begin{tabular}{lrrrrr}
\hline Variabel & N & Minimum & Maximum & \multicolumn{1}{c}{ Mean } & $\begin{array}{c}\text { Std. } \\
\text { Deviation }\end{array}$ \\
\hline ERC & 60 & -14.13 & 7.08 & -3.08 & 8.82 \\
LEVERAGE & 60 & 0.17 & 0.91 & 0.52 & 0.19 \\
BETA & 60 & -1.82 & 1.71 & 0.94 & 0.42 \\
GROWTH & 60 & 0.22 & 9.04 & 1.71 & 1.50 \\
\hline
\end{tabular}




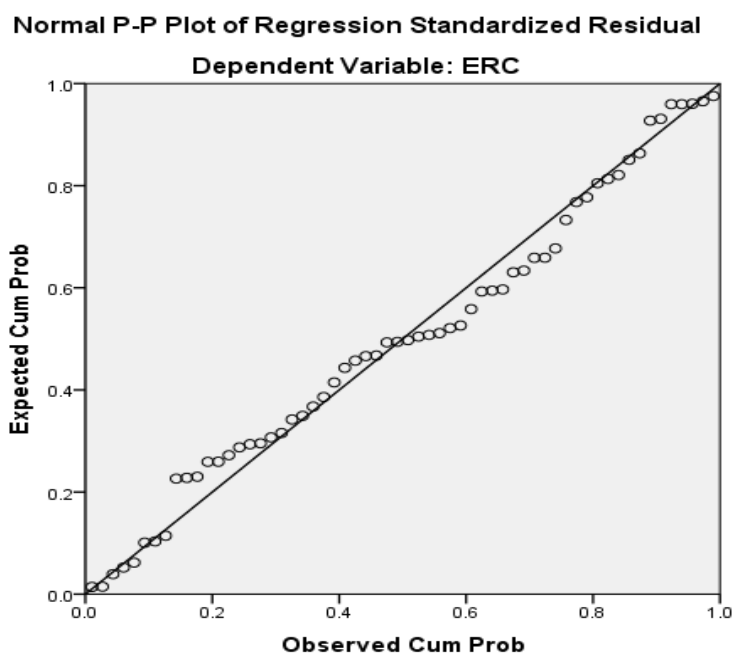

Gambar 1: Hasil Uji Normalitas

Pada output SPSS versi 20.0, P-P Plot of Regrassion data terlihat titik-titik cenderung lurus mengikuti garis diagonal, maka data dapat dianggap terdistribusi normal atau memenuhi asumsi normalitas.

\section{Tabel 3. Hasil Uji Multikolinearitas}

\begin{tabular}{lrr}
\hline Variabel & Tolerance & \multicolumn{1}{l}{ VIF } \\
\hline LEVERAGE & .982 & 1.018 \\
BETA & .928 & 1.078 \\
GROWTH & .654 & 1.528 \\
SIZE & .632 & 1.582 \\
\hline
\end{tabular}

Berdasarkan Tabel 3 dapat dilihat bahwa pada variabel Earnings Response Coefficient (ERC), Leverage, Beta, Growth opportunities dan Size nilai VIF nya dibawah 10 dan nilai tolerance menunjukkan tidak ada variabel independen yang memiliki nilai tolerance kurang dari 0,1 ; dengan demikian variabel-variabel tersebut tidak terjadi multikoliearitas. Uji heteroskedastisitas dilakukan dengan gambar p-plot. Berdasarkan Gambar 2 dapat disimpulkan bahwa tidak ada pola yang jelas, serta titik-titik menyebar dan tidak membentuk pola tertentu, maka tidak terjadi heterokedastisitas.

Gambar 2. Hasil Uji Heteroskedastisitas

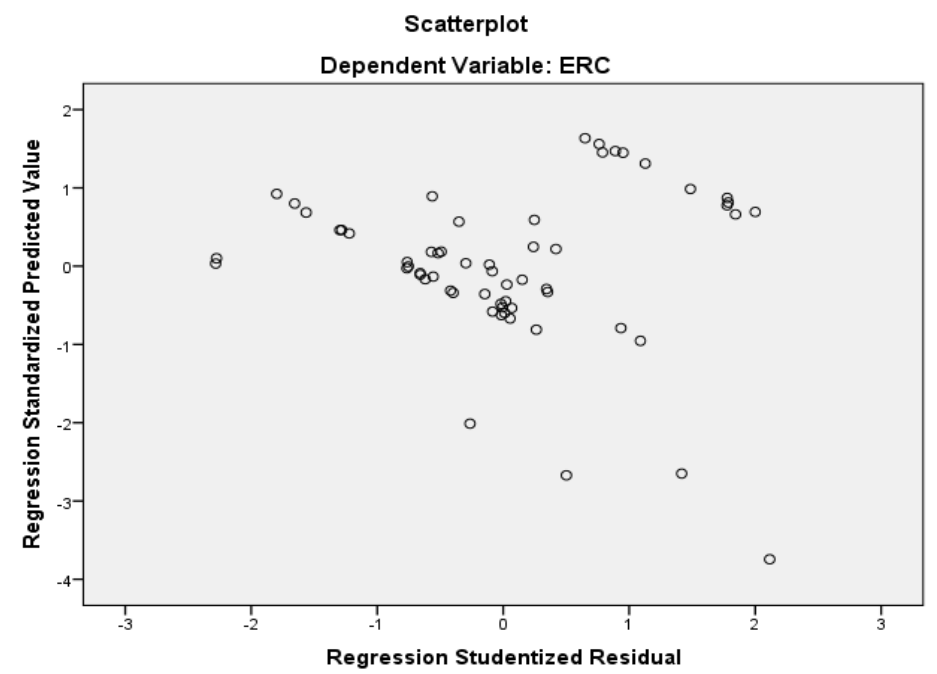


Uji autokorelasi didasarkan pada nilai Durbin Watson. Dari hasil output ditemukan nilai nilai Durbin-Watson yang dihasilkan dari model regresi adalah 2,036. Sedangkan dari tabel DW dengan signifikasi $\alpha 0.05$, jumlah data $\mathrm{n} 60$ dan $\mathrm{k}$ adalah 4, diperoleh nilai dL sebesar 1,4443 dan dU sebesar 1,7274. Nilai 4-dL sebesar 2,5557 dan nilai 4-dU sebesar 2,2726. Dengan demikian dapat disimpulkan bahwa nilai $\mathrm{dU}<\mathrm{DW}<4$-du atau $1,4443<2,036<2,2726$, artinya tidak terjadi autokorelasi.

Uji model penelitian menggunakan hasil uji koefisien determinasi dan Uji F. Uji hipotesis menggunakan Uji t. Rangkuman hasil pengujian sebagaimana Tabel 4.

Nilai $R$ square $\left(\mathrm{R}^{2}\right)$ atau koefisien determinasi digunakan untuk mengukur kemampuan model dalam menerangkan variasi variabel dependen. Nilai $\mathrm{R}^{2}$ adalah diantara nol dan satu. Nilai $\mathrm{R}^{2}$ yang kecil kemampuan variabel independen dalam menjelaskan variabel dependen sangat terbatas. Nilai yang mendekati satu berarti variabel independen memberikan seluruh informasi yang dibutuhkan memprediksi variasi variabel dependen.

Dari hasil pengujian hipotesis diketahui nilai $\mathrm{R}$ sebesar 0,712 (mendekati satu) artinya terjadi hubungan yang sangat kuat antara Leverage, Beta, Growth opportunities dan Firm Size terhadap Earnings Response Coefficient (ERC). Adjusted R Square sebesar 0,622, mempunyai arti bahwa pengaruh secara langsung variabel independen terhadap variabel dependen sebesar $62,2 \%$, sedangkan $37,8 \%$ dipengaruhi oleh faktor lain di luar model yang tidak diikut sertakan dalam penelitian ini yang dikategorikan sebagai error. Standar Error of the Estimate untuk mengetahui banyaknya kesalahan model regresi dalam memprediksi nilai Y. Dari hasil regresi didapat nilai 4,3035 (satuan Earnings Response Coefficient), hal ini berarti banyaknya kesalahan dalam mempediksi Earnings Response Coefficient (ERC) sebesar 4,3035.Pada tingkat keyakinan 95\%, a=0,05, df 1 (jumlah variabel -1) $=4$, df $2(n-k-1)=55$ (60-4-1), maka diperoleh hasil F penelitian sebesar 4.172. Nilai signifikansi didapat $0,000^{\mathrm{b}}$. Nilai ini lebih kecil dari taraf $\alpha 0,05$. Dengan demikian dapat disimpulkam bahwa model regresi yang diuji adalah baik.

Pengujian hipotesis dilakukan dengan uji regresi. Persamaan regresi sebagaimana berikut.

$\mathrm{Y}=1,763-8,202 \mathrm{X} 1-3,081 \mathrm{X} 2+4,078 \mathrm{X} 3+9,447 \mathrm{X} 4$

Dari hasil persamaan regresi linier berganda tersebut, masing masing variabel independen dapat diinterprestasikan pengaruhnya terhadap Earnings Response Coefficient (ERC) sebagai berikut.

1. Jika Leverage $\left(\mathrm{X}_{1}\right)$, Beta $\left(\mathrm{X}_{2}\right)$, Growth opportunities $\left(\mathrm{X}_{3}\right)$ dan Size $\left(\mathrm{X}_{4}\right)$ sama dengan nol, maka nilai Earnings Response Coefficient (ERC) (Y) sebesar 1,763.

2. Setiap kenaikan Leverage $\left(\mathrm{X}_{1}\right)$ sebesar 1 persen dan variabel independen lainnya tetap, maka Earnings Response Coefficient (ERC) mengalami penurunan sebesar 8,20\%. Earnings Response Coefficient (ERC) menurun.

Tabel 4. Hasil Pengujian

\begin{tabular}{lllll}
\hline Keterangan & B & Std. Error & t-hitung & Sig. \\
\hline LEVERAGE & -8.202 & 4.120 & -5.818 & .000 \\
BETA & -3.081 & 3.502 & -.899 & .372 \\
GROWTH & 4.078 & 3.425 & 2.224 & .030 \\
SIZE & 9.447 & 1.834 & 2.887 & .006 \\
Constant & 1.763 & 4.120 & & \\
R-Square & 0.668 & & & \\
Adjusted R-Square & 0.622 & & & \\
F-hitung & 4.172 & & & \\
Sig. F & 0.000 & & & \\
\hline
\end{tabular}


3. Setiap kenaikan Beta sebesar 1 satuan dan variabel independen lainnya tetap, maka Earnings Response Coefficient (ERC) mengalami penurunan sebesar 3,081 persen. Koefisien bernilai negatif artinya terjadi hubungan negatif antara DAR dengan abnormal return saham, semakin meningkatnya beta (risiko), maka Earnings Response Coefficient (ERC) semakin menurun.

4. Setiap kenaikan Growth opportunities sebesar 1 persen dan variabel independen lainnya tetap, maka abnormal return saham mengalami kenaikan sebesar 4,078 persen. Koefisien bernilai positif artinya terjadi hubungan positif antara kesempatan bertumbuh dengan Earnings Response Coefficient (ERC), semakin naik growth opportunities, maka Earnings Response Coefficient (ERC) semakin meningkat.

5. Setiap kenaikan Size sebesar 1 persen dan variabel independen lainnya tetap, maka Earnings Response Coefficient (ERC) mengalami peningkatan sebesar 9,47 persen. Koefisien bernilai positif artinya terjadi hubungan positif antara Size dengan Earnings Response Coefficient (ERC), semakin naik Size, Earnings Response Coefficient (ERC).

Hasil Uji t untuk membuktikan hipotesis menunjukkan bahwa:

1. Hasil pengujian parsial pengaruh Leverage terhadap Earnings Response Coefficient (ERC) menunjukkan $\mathrm{t}$ signifikansi sebesar 0,000 lebih kecil dari tingkat signifikansi 0,05, sehingga secara statistik Leverage berpengaruh secara signifikan terhadap Earnings Response Coefficient (ERC). Koefisien bertanda negatif artinya antara Leverage dan Earnings Response Coefficient (ERC) berhubungan negatif, hal ini menunjukkan bahwajika Leverage meningkat maka Earnings Response Coefficient (ERC) menurun.

2. Hasil pengujian pengaruh Beta terhadap terhadap Earnings Response Coefficient (ERC) menunjukkan $\mathrm{t}$ signifikan 0,372 lebih besar dari tingkat signifikansi 0,05, sehingga secara statistik Beta secara parsial tidak berpengaruh terhadap Earnings Response Coefficient (ERC).

3. Hasil pengujian parsial Growth opportunities terhadap Earnings Response Coefficient (ERC) menunjukkan t signifikan 0,030 lebih kecil dari tingkat signifikan 0,05 , sehingga secara statistik Growth opportunities berpengaruh secara signifikan terhadap Earnings Response Coefficient (ERC). Koefisien bertanda positif artinya antara Growth opportunities dan Earnings Response Coefficient (ERC) berhubungan positif, hal ini menunjukkan bahwa jika Growth opportunities meningkat, maka Earnings Response Coefficient (ERC) juga meningkat.

4. Hasil pengujian parsial Size terhadap Earnings Response Coefficient (ERC) menunjukkan $\mathrm{t}$ signifikan 0,006 lebih kecil dari tingkat signifikansi 0,05 , sehingga secara statistik Size secara parsial berpengaruh signifikan dengan Earnings Response Coefficient (ERC). Koefisien bertanda positif artinya antara Size dan Earnings Response Coefficient (ERC) berhubungan positif, hal ini menunjukkan bahwa jika Size meningkat maka Earnings Response Coefficient (ERC) juga meningkat.

Hipotesis satu $\left(\mathrm{H}_{1}\right)$ untuk mengetahui pengaruh variabel bebas (independent vaiable) Leverage secara parsial terhadap variabel terikat (dependent vaiable) Earnings Response Coefficient (ERC). Tabel distribusi $\mathrm{t}$ pada $\mathrm{a}=$ 0,5, derajat kebebasan (df) 60-4-1 = 55, dengan pengujian dua sisi (signifikasi 0,05 ) diperoleh $\mathrm{t}$ tabel sebesar 2.004, berdasarkan tabel $4.5, \mathrm{t}$ penelitian sebesar 5.818. $\mathrm{t}$ hitung $>$ dari $\mathrm{t}$ tabel $(5.818>2,004)$, maka menerima Ha dan menolak Ho, artinya secara parsial berpengaruh signifikan antara Leverage terhadap Earnings Response Coefficient (ERC); karena koefisien bertanda negatif, maka Leverage berpengaruh negatif terhadap Earnings Response Coefficient (ERC).

Hipotesis dua $\left(\mathrm{H}_{2}\right)$ untuk mengetahui pengaruh variabel bebas (independent variable) 
Beta secara parsial terhadap variabel terikat (dependent variable) Earnings Response Coefficient (ERC). Tabel distribusi $\mathrm{t}$ pada $\mathrm{a}=$ 0,5, derajat kebebasan (df) 60-4-1 $=55$, dengan pengujian dua sisi (signifikasi 0,05 ) diperoleh $\mathrm{t}$ tabel sebesar 2,004, berdasarkan tabel 4.5, $\mathrm{t}$ penelitian sebesar $0,889 . \mathrm{t}$ hitung $<$ dari $\mathrm{t}$ tabel $(0,889<2,004)$, maka menolak Ha dan menerima Ho, artinya secara parsial Beta tidak berpengaruh terhadap Earnings Response Coefficient (ERC). Koefisien bertanda negatif maka Beta berkorelasi negatif terhadap Earnings Response Coefficient (ERC).

Hipotesis tiga $\left(\mathrm{H}_{3}\right)$ untuk mengetahui pengaruh variabel bebas (independent vaiable) Growth opportunities secara parsial terhadap variabel terikat (dependent vaiable) Earnings Response Coefficient (ERC). Tabel distribusi $\mathrm{t}$ pada a $=0,5$, derajat kebebasan (df) 60-4-1 = 55 , dengan pengujian dua sisi (signifikasi 0,05 ) diperoleh $\mathrm{t}$ tabel sebesar 2,004, berdasarkan tabel 4.5, $\mathrm{t}$ penelitian sebesar 2,224. $\mathrm{t}$ hitung $>$ dari t tabel $(2,224>2,004)$, maka menerima Ha dan menolak Ho, artinya secara parsial Growth opportunities berpengaruh signifikan terhadap Earnings Response Coefficient (ERC).

Hipotesis empat $\left(\mathrm{H}_{4}\right)$ ) untuk mengetahui pengaruh variabel bebas (independent vaiable) Firm Size secara parsial terhadap variabel terikat (dependent vaiable) Earnings Response Coefficient (ERC). Tabel distribusi $\mathrm{t}$ pada $\mathrm{a}=$ 0,5, derajat kebebasan (df) 60-4-1 = 55, dengan pengujian dua sisi (signifikasi 0,05) diperoleh $\mathrm{t}$ tabel sebesar 2,004, berdasarkan tabel 4.5, t penelitian sebesar 2,887. $\mathrm{t}$ hitung $>$ dari $\mathrm{t}$ tabel $(2,887>2,004)$, maka menerima Ha dan menolak Ho, artinya secara parsial Firm Size berpengaruh signifikan terhadap Earnings Response Coefficient (ERC).

\section{Pengaruh Leverage terhadap Earnings Response Coefficient (ERC).}

Berdasarkan hasil penelitian yang telah dilakukan, dari persamaan regresi pada hipotesis satu selama periode pengamatan (20082012) menunjukkan bahwa hasil pengujian dengan menggunakan variabel Leverage
$\left(\mathrm{X}_{1}\right)$ berpengaruh negatif signifikan terhadap Earnings Response Coefficient (Y). Hasil uji t menunjukkan $\mathrm{t}$ penelitian lebih besar dari t tabel, hal ini berarti menerima Ha dan menolak Ho. Koefisien bertanda negatif; dengan demikian dapat disimpulkan bahwa secara parsial leverage yang diproksikan dengan Debt to Asset Ratio (DAR) berpengaruh negatif signifikan terhadap Earnings Response Coefficient, hal ini berarti bahwa semakin tingginya hutang perusahaan akan dipandang sebagai beban yang harus ditanggung perusahaan.

Leverage pada perusahaan otomotif yang berpengaruh negatif ini disebabkan karena ratarata hutang jangka panjang perusahaan mengalami penurunan, sementara asset perusahaan mengalami peningkatan, sehingga rasio hutang jangka panjang terhadap asset semakin kecil. Penelitian ini mendukung pendapat Dhaliwal et al. (1991), Sri Mulyani (2003) yang menunjukkan bahwa earnings response coefficient berhubungan negatif dengan tingkat leverage.

\section{Pengaruh Beta Terhadap Earnings Response Coefficient (ERC)}

Hasil pengujian dengan menggunakan variabelBeta $\left(\mathrm{X}_{2}\right)$ menunjukkantidakberpengaruh terhadap Earnings Response Coefficient (Y). Hasil uji $\mathrm{t}$ menunjukkan $\mathrm{t}$ penelitian lebih kecil dari $\mathrm{t}$ tabel, hal ini berarti menerima Ho dan menolak Ha. Beta tidak berpengaruh terhadap Earnings Response Coefficient (ERC), hal ini membuktikan bahwa para investor pada perusahaan otomotif tidak memandang faktor risiko sebagai hambatan dalam berinvestasi. Hal ini tampak pada perkembangan penjualan yang semakin meningkat. Dengan melihat perkembangan tersebut investor optimis akan mendapatkan imbal hasil di masa datang.

Berdasarkan hasil penelitian beta pada perusahaan otomotif secara rata-rata masih di bawah 1 (satu). Hal ini mengindikasikan bahwa investasi pada perusahaan otomotif tingkat risikonya masih kecil, sehingga investor tidak mengalami kekhawatiran. Hasil penelitian ini konsisten dengan hasil penelitian Chandarin (2003) yang didukung oleh hasil penelitian yang 
dilakukan oleh Harahap (2004), dan Jaswadi (2004) yang menyimpulkan bahwa risiko sistematik tidak memberikan pengaruh terhadap ERC.

\section{Pengaruh Kesempatan Bertumbuh (Growth opportunities) Terhadap Earnings Response Coefficient (ERC)}

Hasil pengujian dengan menggunakan variabel growth opportunities $\left(\mathrm{X}_{3}\right)$ menunjukkan berpengaruh terhadap Earnings Response Coefficient (Y). Hasil uji $\mathrm{t}$ menunjukkan $\mathrm{t}$ penelitian lebih besar dari t tabel, hal ini berarti menerima Ha dan menolak Ho. Hasil penelitian menunjukan bahwa perusahaan otomotif yang memiliki kesempatan bertumbuh besar akan memiliki ERC tinggi. Kondisi ini menunjukkan bahwa semakin besar kesempatan bertumbuh perusahaan maka semakin tinggi kesempatan perusahaan mendapatkan atau menambah laba yang diperoleh perusahaan pada masa mendatang.

Pada perusahaan otomotif ditandai dengan peningkatan investasi yang ditunjukkan dengan bertambahnya tempat-tempat perakitan perusahaan tersebut diseluruh wilayah dan tingginya peningkatan penjualan, ini menunjukan pertumbuhan perusahaan meningkat tajam. Growth opportunities yang diproksikan dengan Price to Book Value Ratio (PBVR). Studi temuan ini konsisten dengan Collins dan Kothari (1989) yang menunjukkan bahwa perusahaan yang memiliki kesempatan bertumbuh yang lebih besar akan memiliki Erning Response Coefficient (ERC) tinggi.

\section{Pengaruh Firm Size terhadap Earnings Response Coefficient (ERC)}

Hasil pengujian dengan menggunakan variabel Firm Size $\left(\mathrm{X}_{4}\right)$ menunjukkan berpengaruh terhadap Earnings Response Coefficient (Y). Hasil uji $\mathrm{t}$ menunjukkan $\mathrm{t}$ penelitian lebih besar dari $\mathrm{t}$ tabel, hal ini berarti menerima $\mathrm{Ha}$ dan menolak Ho. Hasil penelitian ini menunjukkan bahwa berdasarkan pertumbuhan perusahaan yang berukuran besar akan lebih cenderung untuk melakukan praktik perataan laba dibandingkan perusahaan kecil, karena perusahaan besar cenderung mendapatkan perhatian yang lebih besar dari investor dibandingkan perusahaan kecil. Sebaliknya perusahaan yang memiliki Asset besar yang kemudian dikategorikan sebagai perusahaan besar dalam bidang otomotif dan komponen misalnya Astra Int'l Tbk, dan Indomobil pada bidang otomotif dan Goodyear Indonesia Tbk pada bidang komponen umumnya akan mendapat lebih banyak perhatian dari berbagai pihak seperti, para investor, maupun pemerintah. Dengan demikian total asset yang besar mencerminkan Earnings Response Coefficient yang baik, sehingga ukuran perusahaan berpengaruh terhadap Earning Respon Coefficient. Penelitian ini membuktikan bahwa besaran perusahaan merupakan variabel penjelas yang signifikan untuk earnings response coefficient.

\section{Simpulan, Keterbatasan, dan Implikasi Hasil Penelitian}

Berdasarkan hasil analisis dan pembahasan yang telah diuraikan sebelumnya, penelitian ini dapat disimpulkan sebagai berikut.

1. Leverage yang diproksikan dengan Debt to Asset Ratio (DAR) berpengaruh negatif signifikan terhadap Earnings Response Coefficient.

2. Risiko Sistimatis (Beta) tidak berpengaruh terhadap Earnings Response Coefficient (ERC),

3. Kesempatan bertumbuh (Growth opportunities) yang diproksikan dengan Price to Book Value Ratio (PBVR), berpengaruh signifikan terhadap Earnings Response Coefficient.

4. Ukuran perusahan (Firm Size) berpengaruh signifikan terhadap Earnings Response Coefficient.

\section{Daftar Rujukan}

Alwi, S., 1994, Alat-Alat Analisis Dalam Pembelanjaan, Andi Offset: Yogyakarta.

Andayani, Asyik, N. F, Mulyani,. 2007. FaktorFaktor yang mempengaruhi Earnings Response Coefficient Pada Perusahaan 
yang Terdapat Di Bursa Efek Jakarta. Jurnal Akuntansi dan Keuangan. STIESIA Surabaya.

Anoraga, P., Pakarti, P., 2001, Pengantar Pasar Modal, Edisi Revisi, Rineka Cipta : Jakarta.

Cho, L.Y., and K. Jung. 1991. Earnings Response Coefficients: A Synthesis of Theory and Empirical Evidence. Journal of Accounting Literature Vol.10. pp 85-116.

Claude et. Al., 1996, Political Risk, Economic Risk and Financial Risk, Financial Analysts Journal, November-December

Departemen Keuangan RI, BAPEPEM. 2006. Keputsan Nomor:KEP-134/BL/2006, tentang Kewajiban Penyampaian Laporan Keuangan Tahunan Bagi Emiten Atau Perusahaan Publik

Ermayanti, D., 2009. Income Laba. Available at http://dwiermayanti.wordpress.com diakses pada 15 Maret 2010 Badan Penerbit Universitas Diponegoro.

Harahap, S. S. 2007. Analisis Kritis Atas Laporan Keuangan. Jakarta: PT. Raja Grafindo Persada

Husnan, S. 2003. Dasar-Dasr Teori Portofolio dan Analisis Sekuritas Yogyakarta: BPFE Yogyakarta.

Husnan, S., Pudjiastut, E., 2004, Dasar-dasar Manajemen Keuangan, Edisi keempat, YKPN : Yogyakarta.

Indra,A.Z., Zahron,A., dan Rosianawati,A., 2011. Analisis Faktor-faktor yang mempengaruhi Earnings Response Coefficient Studi pada Perusahaan Properti dan Real Estate yang Terdaftar di BEI

Jogiyanto. 2009. Teori Portofolio dan Analisis Investasi. Yogyakarta : BPFE Yogyakarta.

Moradi,Mehdi.Salehi, Mahdi. Erfanian, Zakiheh. 2010 A Study of Financial Leverage on ERC Throught Out Income Approach: Iranian Evidance.

Mulyani, S., Nur F.A., dan Andayani,. 2007 Faktor-faktor yang mempengaruhi Earnings Response Coefficient ERC pada perusahaan yang terdaftar di BEI. Jurnal Akuntansi dan Auditing Indonesia Vol.1, No.1 Hal:35-45

Murwaningsari, E., 2008 Beberapa faktor yang memepengaruhi Earnings Response Coefficient ERC. Simposium Nasional Akuntansi SNA ke XI, Pontianak.

Naimah, Z., Utama, S., 2006 Pengaruh Ukuran Perusahaan, Pertumbuhan Laba Dan Profitabilitas Perusahaan Terhadap Earnings Response Coefficient Dan Koefisient Respon Nilai Buku Ekuitas. Simposium Nasional IX

Palupi, M. J., 2003. Faktor-faktor yang mempengaruhi Earning Response Coefficient pada perusahaan yang terdaftar di Bursa Efek Jakarta .Jurnal Akuntansi

Riyanto, Prof. Dr. Bambang., 2001, Dasar-dasar Pembelanjaan Perusahaan, Edisi 4, BPFE : Yogyakarta.

Van Horne, James., 2000, Financial Management and Policy, Prentice Hall : New Jersey.

Weston, J. Freed, and Scott Besley, and Eugene F. Brigham., 2001, Essential of Managerial Finance, The Dryden Press : New York. 